\title{
Headline's Meaning in On-Line Football Sport News
}

\author{
Gina Larasaty, S.S., M.Pd. \\ S1 English Education Department \\ Wiralodra University, Indramayu
}

\begin{abstract}
The title of this study is Headline's meaning in On-Line Football Sport News. The aims of this study are to describe the real meaning meaning contained in headline of on-line football sport news and to find out whether the meanings that appears in that headline and choice of words in the headline can represent the contents of the news, view from semantics study study. The data are taken and collected from headline of on-line football sport news from website Goal.com. In my study, the writer collected 20 data and analyzed it. The research method used in this study is descriptive method. The result shows that from 20 headlines, all of them can represent the content of the news and the words are used in the headline has conceptual and associative meaning that set in situational context. Based on the data, We can assume that headline always uses an unusual diction and has an implicit meaning to attract the attention of the reader. To attract the reader, Headline News use an unusual diction (figurative language, make it simple and direct). Then, based on this study, we can assume that from the headline we can know the contet or what the news is talking about.
\end{abstract}

\section{Keywords ; Meaning, Headline, On-line news and situational context}

\section{INTRODUCTION}

Nowadays, technological developments influenced the development of information especially in the news (journalism). In journalism we known as on-line news, by internet we can access news anytime, anywhere easily. The advantage of on-line news is always update anytime different from newspaper.

One of the important thing from news is the "headline". According to Hoeta Soehoet $(2003 ; 78)$, "Headline" is the leading news according to editorial judgment that is the most important news of all the news is presented in the paper in that day. So the headline has a function to draw the reader's interest. The writing of headline is made in such a way to be interesting, both in the way of writing that uses large fonts and even an unusual choice of words (diction) such as the use of style. The use of style in headlines sometimes cause a variety of meanings. Therefore, the 
authors are interested in analyzing the associative meanings contained in the headline that set in situational context.

Sports news is the most preferred alternative news at this time, it is proven evidenced by many television programs that show sports news, especially football. Therefore the authors chose "Meanings in Headline On-line Sport news" as the title of our research.

\section{LITERATURE REVIEW}

\section{Theories of Meaning}

In Semantics: The Study of Meaning (1974), British linguist Geoffrey Leech introduced the term associative meaning to refer to the various types of meaning that are distinct from denotation (or conceptual meaning): connotative, thematic, social, affective, reflective, and collocative.

\section{Theories of situational context}

In analysis of data, the writer focus on the context of the situation. According to Hymes, situational context is knowledge of who is speaking, who is listening, what objects are being discussed, and general facts about the world we live in, used to aid the interpretation of meaning (2002:594). "a text is a linguistic form of social interaction and its environments the context of situation, which is one of instance of a situation type. A situation type is a semiotic construct, structured in terms of field, tenor, mode". In conclusion situational context is a text that is a form of linguistic from social interaction and its environment.

\section{Research Question}

- What is the meaning that appears in that headline and choice of words in the headline can represent the contents of the news?

\section{RESEARCH METHOD}

This study employs descriptive method, according to Tarigan (1993: 103) descriptive method is a research study that collects or involves a set of techniques used to define, describe or provide the scientific phenomena that occur without experimental manipulation. In this study, the authors collected data from the headlines taken from the site www.goal.com. Data were analyzed semantically based on register (situational context) to determine the meaning contained and whether it can represent the content of headline news, and draw conclusions from all the analysis has been done. 


\section{FINDING AND DISCUSSION}

The findings show that in 20 data collected, it was found that the diction in the headline is different from the others headline such as political news, etc. Headline on the sports news using a lot of style and of course the meaning is implied. The occurrence that the words used in the headline contains conceptual and associative meaning that set in situational context. Such as:

\section{Headline's Meaning}

\begin{tabular}{|c|c|c|}
\hline Headlines & Conceptual Meaning & Assosiative Meaning \\
\hline Return of the king & $\begin{array}{l}\text { Coming back of male } \\
\text { ruler of an independnt } \\
\text { state }\end{array}$ & $\begin{array}{l}\text { The coming back of } \\
\text { javier aguirre as } \\
\text { manager of Mexico } \\
\text { Team }\end{array}$ \\
\hline Feeling at Home & $\begin{array}{l}\text { Feeling pleasure and } \\
\text { comfort like in a home }\end{array}$ & $\begin{array}{l}\text { Feeling comfort join in } \\
\text { Chelsea club }\end{array}$ \\
\hline Debut Dagger & $\begin{array}{l}\text { The first performance of } \\
\text { short pointed knife. }\end{array}$ & $\begin{array}{l}\text { The first outstanding } \\
\text { public appearance of } \\
\text { Yuri Zhirkov. }\end{array}$ \\
\hline Irons to contest charges & $\begin{array}{l}\text { The refusal of the hard } \\
\text { strong metals }\end{array}$ & $\begin{array}{l}\text { West Ham United and } \\
\text { Lyons refuse FA charges } \\
\text { over violance }\end{array}$ \\
\hline Ready to Rumble & $\begin{array}{l}\text { Ready to make series of } \\
\text { sound. }\end{array}$ & $\begin{array}{l}\text { Time for Irenland to win } \\
\text { and shine }\end{array}$ \\
\hline Free as bird & $\begin{array}{l}\text { Not tied up or in a cage } \\
\text { like the birds fly in the } \\
\text { sky. }\end{array}$ & $\begin{array}{l}\text { Chirtiano Ronaldo feels } \\
\text { more able to express } \\
\text { himself in Spanyol Club. }\end{array}$ \\
\hline Life as a red & $\begin{array}{l}\text { The state of being alive } \\
\text { as having the color of } \\
\text { blood or fire }\end{array}$ & $\begin{array}{l}\text { Daniel Agger feels } \\
\text { happier to play again for } \\
\text { Liverpool. }\end{array}$ \\
\hline $\begin{array}{l}\text { Top of CONCACAF } \\
\text { hex }\end{array}$ & $\begin{array}{l}\text { The high position of } \\
\text { CONCACAF }\end{array}$ & $\begin{array}{l}\text { The Greatest of } \\
\text { American National team }\end{array}$ \\
\hline Flew the Coop & Escape from & $\begin{array}{l}\text { Transfering of Cooper } \\
\text { FC Dallas for TSV } 1860 \\
\text { Munich was disclosed }\end{array}$ \\
\hline Irish invansion & $\begin{array}{l}\text { The irish people act off } \\
\text { an army entering another } \\
\text { country by force to take } \\
\text { control }\end{array}$ & $\begin{array}{l}\text { Domenech worried } \\
\text { about Ireland supporter }\end{array}$ \\
\hline The Blue shield & $\begin{array}{l}\text { A thing that having blue } \\
\text { color used to protect the } \\
\text { body }\end{array}$ & $\begin{array}{l}\text { Chelsea is the winner of } \\
\text { Community shield }\end{array}$ \\
\hline
\end{tabular}




\begin{tabular}{|c|c|c|}
\hline Western draw & $\begin{array}{l}\text { To finish the game } \\
\text { without either team } \\
\text { connected with west part } \\
\text { of the world winning }\end{array}$ & $\begin{array}{l}\text { Goalles draw between } \\
\text { houston and los Angles } \\
\text { team }\end{array}$ \\
\hline Flight of the Kiwis & $\begin{array}{l}\text { Flight of the the New } \\
\text { Zealand birds }\end{array}$ & $\begin{array}{l}\text { New Zealand have an } \\
\text { big opportunity in World } \\
\text { Cup }\end{array}$ \\
\hline Azteca Awaits & $\begin{array}{l}\text { The stadium in Mexico } \\
\text { is waiting for }\end{array}$ & $\begin{array}{l}\text { Mexico ready to } \\
\text { challenge the U.S team } \\
\text { in Azteca stadium. }\end{array}$ \\
\hline Citizens held & $\begin{array}{l}\text { Controlling people who } \\
\text { live in particular place }\end{array}$ & $\begin{array}{l}\text { The defense done by } \\
\text { Manchaster United } \\
\text { squad. }\end{array}$ \\
\hline Algerians Attacked & $\begin{array}{l}\text { Algerian citizens was } \\
\text { attacked }\end{array}$ & $\begin{array}{l}\text { The bus of Algerian } \\
\text { national team was } \\
\text { attacked in Egypt. }\end{array}$ \\
\hline New York wins & $\begin{array}{l}\text { The most successful in a } \\
\text { competition of New } \\
\text { York city }\end{array}$ & $\begin{array}{l}\text { Waiting of Red bulls to } \\
\text { get Victory in MLS }\end{array}$ \\
\hline Clear as mud & Easy to see like wet soil & $\begin{array}{l}\text { Hard prediction for the } \\
\text { winner of CONCACAF } \\
\text { World Cup qualifying }\end{array}$ \\
\hline Heatbreak at Anfield & $\begin{array}{l}\text { Strong feeling of } \\
\text { sadness in Anfield } \\
\text { stadium }\end{array}$ & $\begin{array}{l}\text { Liverpool's failure in } \\
\text { Anfield }\end{array}$ \\
\hline Wary of Atleti & $\begin{array}{l}\text { Careful when dealing } \\
\text { with Atletico club }\end{array}$ & $\begin{array}{l}\text { Chelsea should not } \\
\text { underestimate Atletico } \\
\text { Madrid }\end{array}$ \\
\hline
\end{tabular}

\section{Discussion}

In this discussion, the writer tried to discuss whether the headline can represents the content of the news or not. The first, the writer should find out the meaning of the headlines, headlines has more than one meaning, so to make the right meaning the writer should connected to the situational context. To find out the situational context, it can be analyzed with field, mode, and tenor. After that, making connection between Headline's meaning and situational context. Based on that, we can know whether headline's news can represents the content of the news. For example:

\section{1) Return of the king}

Javier Aguirre once ruled, in 2015. Aguirre's legend began when he returned around Mexico's near-dead hopes of reaching the world cup. Now , he returns once again to lead Mexico back to prominence once more. 
Aguirre's first official day on the job was Thursday and he addressed the media for...

The conceptual meaning contained in the headline above is "coming back of male ruler of an independent state (oxford dictionary). The meaning of " coming back of male ruler of independent state" has another meaning, it has another association based on the contain of the news. when viewed from situational context (what is being said in that language) that is about one former manager Javier Aguirre who was asked back to Mexico national team as manager. and the meaning of the king here is Javiere Aguirre. So the headline has associative meaning as " the return of Javiere Aguirre in Mexico national team as manager".

\section{2). Irish Invasion}

With their opponent picked out, French couch Raymond Domenech is hoping for the best when the two team's square off for a place in next summer's world cup. The manager is worried that the Irish will send a formidable number of supporters to Paris, which could hinder his team...

The conceptual meaning that is contained in Headline "Irish Invasion" is " the Irish people act of an army entering another country entering another country by force to take control". When the meaning above is related to the content of the News, it is less appropriate. Based on the content of News, it was talking about the concerns about the arrival of Irish Supporters in large number. So, "Irish Invasion" has another meaning. The headline is associated to Domenech worried about Ireland Supporters.

\section{CONCLUSION}

In Journalism, writing News needs a certain technique. The conventional way of writing news (short, clear and brief) changes to the new style, that is a style more in - depth. It can be seen from the meaning and form, that is a style has implicit meaning which can only be understood through reference of context.

To conclude, this discussion shows that the words used in the headline contains conceptual and associative meaning that set in situational context. Based on the result. We can assume that headline always uses an unusual diction and has an implicit meaning to attract the attention of the reader. The headline can be understood by reference of context. Even though, the words that is used in Headline has associative meaning, the headline able to refer the content of News. The this technique able to attract the reader to read News. 


\section{REFERENCES}

Hyams, Nina dan fromkin. 2010. An Introduction to Languge . Wadsworth: USA

Hoeta Soehoet, A.M, (2003). Dasar Dasar Jurnalistik, Yayasan Kampus Tercinta, IISIP, Jakarta.

Huford, James R. (2007). Semantics A Coursebook. Cambridge University Press: Cambridge

Leech, Geoffrey. (1974) Semantics the study of meaning. Great Britain : Pinguins Book

Tarigan ,H.G. (1993). Strategi Pengajaran dan Pembelajaran Bahasa. Bandung : Angkasa

www.goal.com. 